\title{
Editorial
}

\section{Revista Enfermagem UERJ: superação em 25 anos de contribuição científica nacional e internacional}

Em junho de 1993 era publicado o primeiro fascículo da Revista enfermagem UERJ. No formato impresso, produzido pela Editora Cultura Médica Ltda $^{\circledR}$, já trouxe em seu primeiro editorial uma narrativa da Profa. Ms. Maria Therezinha Nóbrega da Silva sobre a superação de obstáculos da Faculdade de Enfermagem da Universidade do Estado do Rio de Janeiro (ENF-UERJ) para sua inserção no cenário científico nacional ${ }^{1}$.

Nascendo da intenção de "cumprir um papel na veiculação de ideias e edificar um corpo teórico de enfermagem comprometido com os problemas de sobrevivência das pessoas e coletividades e suscitador de reflexões e propostas capazes de Estimular o pleno exercício da cidadania de seus leitores" ${ }^{\prime 1}$, a Revista enfermagem UERJ manteve-se fiel à sua proposta. Atualmente, publica trabalhos que contribuam para o conhecimento e desenvolvimento da enfermagem, da saúde e ciências afins, sendo um periódico de circulação internacional, abrangendo predominantemente os países da América Latina e Caribe, embora também tenha circulação nos Estados Unidos, Canadá, França, Suécia, Portugal e Espanha.

Porém, para o alcance dessa abrangência, o corpo editorial, liderado, em diferentes períodos, pelos professores Dra. Iraci dos Santos (1993-1997), Dra. Maria Yvone Chaves Mauro (1998-1999), Ms. Araci Carmen Clos (2000-2001), Dra. Denize de Oliveira (2002-2008) e Dr. Octavio Muniz da Costa Vargens (2008-atual), enfrentou (e enfrenta) o desafio de manter a qualidade e integridade mesmo diante de cenários adversos.

Neste contexto, destacam-se as dificuldades enfrentadas mais recentemente, a partir de 2015, quando uma crise econômica e política sem precedentes interrompeu um dos melhores ciclos de financiamento contínuo à pesquisa e pós-graduação já observado no Brasil. No Rio de Janeiro, houve significativo comprometimento científico e tecnológico, com estrangulamento dos recursos voltados à Universidade do Estado do Rio de Janeiro - UERJ, Universidade Estadual do Norte Fluminense - UENF e Fundação Centro Universitário Estadual de Zona Oeste UEZO, que tiveram seus recursos para pesquisas minguados².

Consequentemente, a UERJ viveu um longo período de crise, não apenas sem financiamentos, mas também sem salários pagos a seus servidores, por períodos superiores a 100 dias e greve de seu corpo social.

A manutenção da Revista Enfermagem UERJ durante e após esse período configurou-se como intenso desafio, que vem sendo superado com o apoio do corpo administrativo e docente da Faculdade de Enfermagem, dos editores da própria revista e de periódicos da área do estado do Rio de Janeiro e do cenário nacional. Somam-se a estes os autores que acreditam na idoneidade e potencialidade de nossa revista ao continuarem submetendo seus manuscritos.

Foram até aqui 25 anos de luta em prol da ciência e da evolução do conhecimento, com aproximadamente 1.730 artigos publicados. Iniciamos como publicação impressa semestral, passando à periodicidade quadrimestral em 2001, trimestral em 2006. Em 2012 evoluímos para publicações impressa e eletrônica com periodicidade bimestral. A exclusividade de publicações eletrônicas chegou em 2014, bimestralmente, e, a partir de 2017 passamos a publicar em fluxo contínuo. Desde 2013, nossas publicações passaram a ser oficialmente bilíngues, nos idiomas português e inglês.

Em 2010 alcançamos a indexação na base SCOPUS, que nos projetou definitivamente no cenário internacional. Com a criação do portal Rev@Enf da BVS Enfermagem, passamos a integrar sua coleção a partir do volume 12 de 2004. Em mais um esforço de superação, estamos atualizando nossa presença nesse importante portal.

É nítido que o futuro das universidades públicas é incerto, mas o seguimento da política editorial compromissada com publicações que contribuam com o avanço da ciência e mantenham o engajamento com o avanço social e da cidadania são uma responsabilidade da Revista Enfermagem UERJ.

\section{Cristiane Helena Gallasch Editora Associada}

\section{Octavio Muniz da Costa Vargens}

Editor Científico

\section{Referências}

1. Silva MTN. Editorial. Rev enferm UERJ. 1993; 1(1):1.

2. Moura EG, Camargo Junior KR. A crise no financiamento da pesquisa e pós-graduação no Brasil. Cad. Saúde Pública[Internet]. 2017[Acesso 19 Dez 2018]; 33(4):e00052917. Doi: 10.1590/0102-311X00052917 